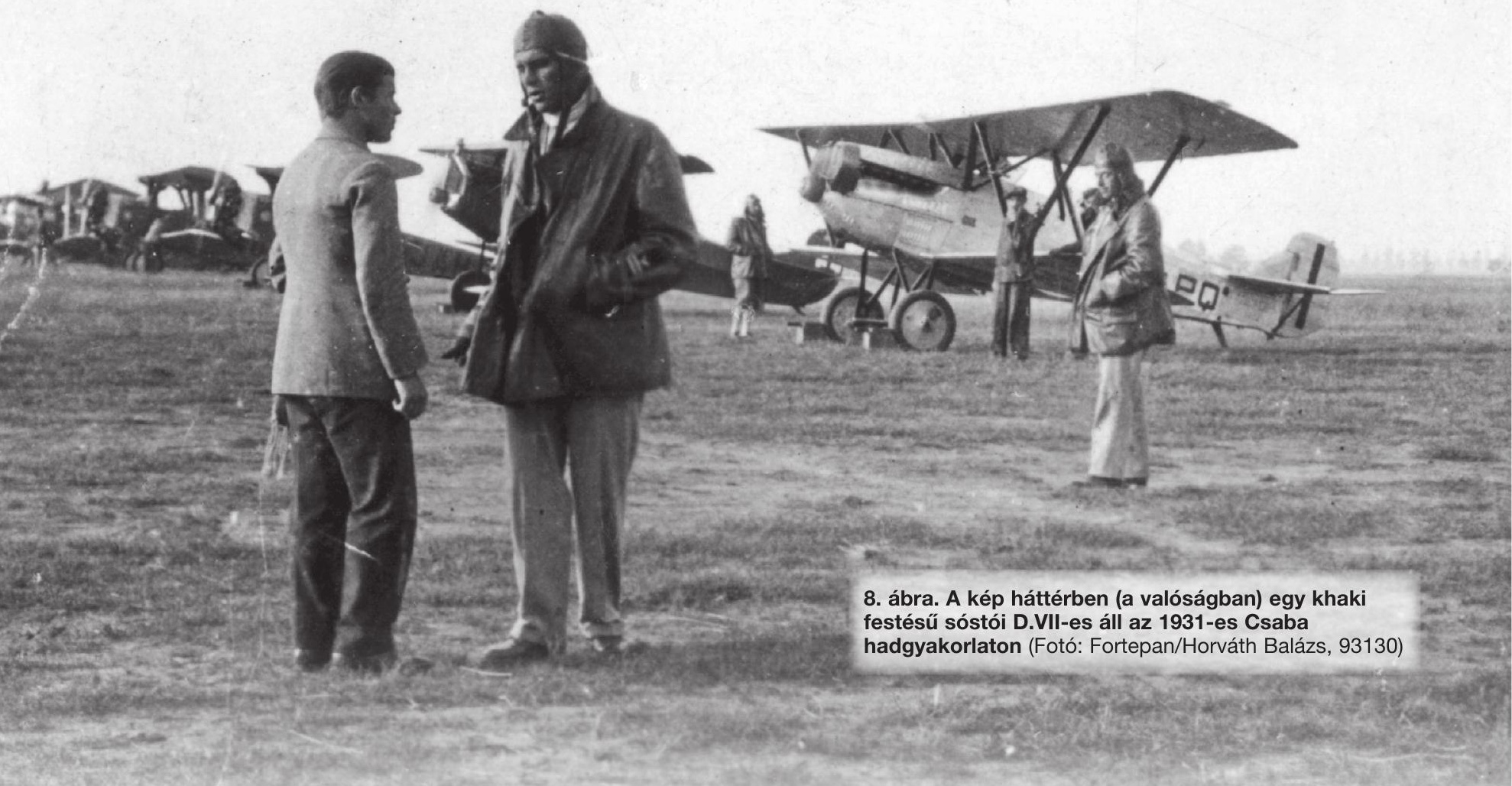

Hajdu Péter*

\title{
A magyar Fokker D.VII-es vadászrepülőgépek története m.ress
}

A cikk I. része a Magyarországra került és itt gyártott Fokker D.VII-es vadászrepülőgépek alkalmazásának történetét mutatta be a Tanácsköztársaság kikiáltásáig (1919. március 21.). Ebben az epizódban tovább követjük a gépek magyar vörös repülőcsapatoknál végzett működését. Különös figyelmet érdemel a HD.09 lajstromszámú vadászgépről szóló bekezdés, amely mindeddig nem publikált, új kutatási eredményekről is beszámol. Végül a Nemzeti Hadsereg légierejének egyetlen nagy hadmúveletében való részvételéről, és a harci repülők polgári célokra átalakításáról olvashatunk.

$\mathrm{Az}$ új szervezeti egységben a Fokker vadászokat a 8 . vörös ${ }^{1}$ repülőszázadban vonták össze, az 1-7. felderítő (bombázó) repülőszázadokat pedig 1-1 hadosztály mellé osztották be, de némelyiket még pár Berg vadászgéppel is megerősítették. Budapest körül légi figyelő láncolatot építettek ki, míg Mátyásföldön 1 vadász reggeltől estig, 1 másik enyhébb fokozatban állt készültségben [12, 16, 20]. Miközben a román előretörést a Székely Hadosztály egymaga képtelen volt feltartóztatni, azalatt a Fokkerek az új - fehér mezőben vörös csillagos - felségjellel Budapesten tartottak légi bemutatókat a munkásdemonstrációk felett
1919. április 23-án és május 1-jén. Májusban a románokat a Tiszánál megállították, később a cseheket kezdték viszszaszorítani [24, 30].

A 8. repülőszázad kisebb-nagyobb különítményekkel települt a nagyobb ütközetek közelébe: május végétől június közepéig részt vettek a miskolci csatákban, június végén $9 \mathrm{db}$ vadásszal Győrt védték a cseh és francia repülőktől, utána Vácról, legvégül júliusban Újszászról támogatták a tiszai offenzívát. Egy légi győzelmet is arattak, június 12-én Sajószöged felett lelőtték a román színekben repülő 161.156 UFAG C.I-t [5, 7, 12, 24, 26, 28]. A lelövést Újvári László $(9)^{2}$ és Keisz Géza pilóták aratták D.VII-esekkel. Több sikeres alacsonytámadást is végeztek, ebből kiemelkedik a június 1-én a tiszalúci támadás [5, 299-306. o., 20, 24, 30], ahol Újvári László, Keisz Géza és Hefty Frigyes $(5+4)$ négy cseh üteget géppuskázott végig 10-20 m-re leereszkedve. Az ellenséges ágyúk elhallgattatása feltétele volt a sikeres magyar támadásnak. Az utolsó légvédelmi feladatra július 29-én a Miskolc felett repülő francia eredetű hárommotoros Farman nehézbombázó repülőgép üldözésére szállt fel az Újvári László, Risztics János $(7+1)$ és Kasza Sándor (6) pilótákból álló D.VII-es raj, amelyhez

ORCID: 0000-0002-8841-4173 


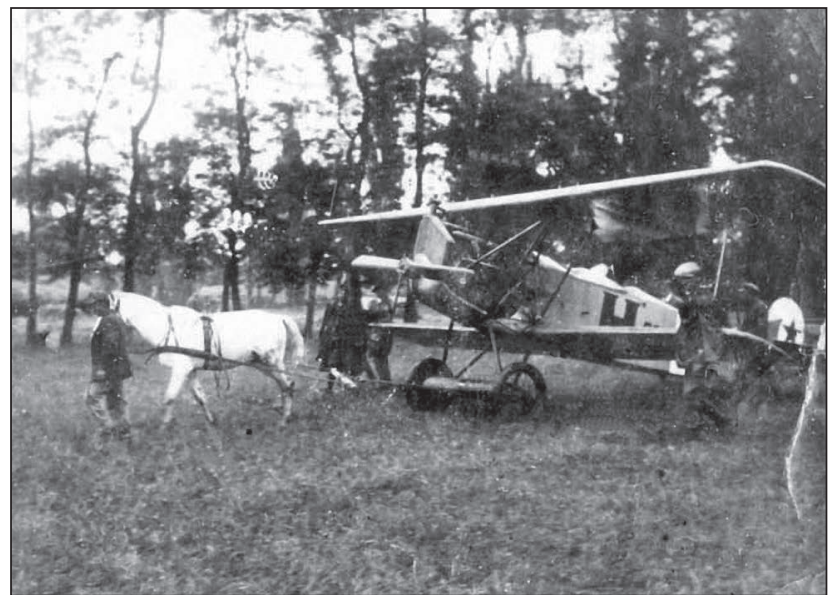

9. ábra. Ló vontatta kétüléses MÁG Fokker C.I-es. A „H” betű formája, a nagynak látszó szám, a bal kerékvédő lemez hiánya és a légcsavar formája alapján, a fotón nagy valószínűséggel a H.02-es Fokker látható

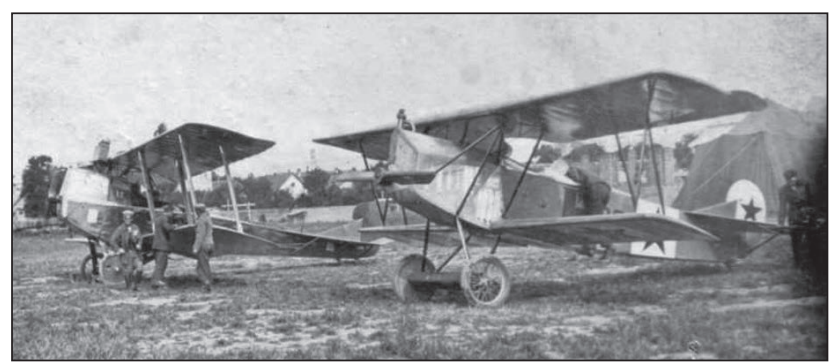

10. ábra. Egy 1919. 06. 05. és 15. között Pásztón készült fotó a H.02-es kétüléses C.I-ről. Egy visszaemlékező szerint rendelkezett géppuskával [8]

csatlakozott egy D.VI-os is. A repülőt meglátták, de az a zárt felhőtakaróba emelkedve egérutat nyert. Vadász feladatok mellett több felderítést is végeztek, többnyire a veszélyes területek felett, és néhány front mögötti alacsonytámadásról is maradtak fent jelentések, mint pl. a nemesócsai légiós repülőtér géppuskázása [5, 12, 24].

Májusban még a német D.VII-esek voltak többségben, de június-júliusban megérkeztek a 8 . repülőszázadhoz a Magyar Általános Gépgyár (MÁG) építésű D.VII-esek is, valószínúleg a 93.02-93.09-es lajstromszámúak. De a század továbbra is használta a többnyire egy géppuskával felszerelt D.I Bergeket és a Fokker D.VI-osokat is $[5,6,7,12]$.

Néhány Fokker C.I-es is került az egységbe, a H.02 (amely azután rövidesen elkerült) és a H.08. Nincs konkrét adat, de gyanítható a H.03-as bevetése is, hiszen nem szerepel a zsákmánylistákban. Futárszolgálaton kívül használta az egység felderítésre (Háry László századparancsnok sürűn repült velük), az egyik kétülésest a Kassa feletti bevetésnél egy D.VII-es is kísérte [5, 8, 12, 24].

Más századokhoz került Fokkerekről szintén kevés információval rendelkezünk. A június végén, Rákoson felálított másik vadászrepülő-egységet, a 10. repülőszázadot papíron csak Aviatik D.I vadászokkal szerelték fel. Üveges József fényképész a rákosi repülőtéren készült fotóján azonban 3 db német és MÁG-gyártású D.VII-es látható a gépek között. A rákosi 3. repülőszázad állományában június elején tűnik fel a H.02 kétüléses Fokker C.I, pilótája Deutsch István. Egy kihelyezett négygépes különítmény részeként először Losoncról, Pásztóról, majd az anyarepülőtérről végzett felderítéseket a Felvidék felett, legalább 3 alkalommal alacsonytámadást végzett, egyszer vonuló tüzérség más- kor tehervonat, valamint teherautók ellen. Vadászként pedig Zólyom felett sikertelenül próbált utolérni egy ellenséges repülőgépet. Deutsch július 20-án Ongára repült (3 felderítőszázadtól 1-1 vadászgépet vezényeltek ebbe a különítménybe), de útközben kényszerleszállást hajtott végre, a H.02-ről ezután nincs több információ $[5,8,12]$.

Hogy a 8. repülőszázad éppen hol jelent meg, és harcolta ki rövidesen a légi fölényt (Miskolc, Győr stb.) azt az alábbi tényezők határozták meg: a kor legjobb vadászgépének, a Fokker D.VII-esnek alkalmazása - amelyek botkormányai mögött tapasztalt magyar pilóták és repülöászok ültek -, valamint az a taktika, hogy egyszerre 2-3 vadászrepülö cirkált, vagy vette üldözőbe a többnyire egyedül repülő ellenséges gépeket. Megjegyzendő, hogy az 1919-es légi háború erőviszonyai a magyaroknak kedveztek. A csehek csupán 2 repülőszázaddal vettek részt a harcokban, ezért júniusban a francia BRE 590 repülőszázadot Pozsonyba vezényelték támogatásukra. A 3 harci századdal rendelkező románok is igyekeztek a zsákmányolt repülőket üzembe helyezni [5, 12, 24]. A magyarok ezzel szemben $7 \mathrm{db}$ felderítő, 1 vadász és 1 vízi repülőszázaddal rendelkeztek, és júliusban a 10. vadászrepülő-század is megalakult, de még a kiképzőszázad is hadra fogható volt, lásd az ellenforradalmárok elleni bombázásaikat.

A július végi vesztes tiszai ütközetek után a Tanácsköztársaság Forradalmi Kormányzótanácsa augusztus 1-jén lemondott, és a románok augusztus 4-én bevonultak Budapestre. A MÁG repülőgyárban többek között 1 originál Fokkert és egy motor beszerelésre váró D.VII-est foglaltak le, ugyanis a már kész repülőket korábban a Cinkotai Anyagszertárba raktározták be. A vadonatúj D.VII-eseket és C.I-eseket onnen szállították el - ellentételezés nélkül Romániába [10, 24].

Ezenkívül az alábbi magyar (vörös) D.VII-esek elvesztéséről van tudomásunk, zömmel a 8. repülőszázad állományából: május 27-én Fejes István (17+4) 3867-es számú német Fokkerének saját géppuskája átlőtte a légcsavarját, Losoncnál kényszerleszállást hajtott végre és elfogták. Június 1-jén Hefty Frigyes lábát alacsonytámadás során géppuskalövedékkel eltalálták, Mezőcsát térségében - a vadászrepülő jobb kerekének korábbi elvesztése miatt kényszerleszálláskor átvágódott [5, 12, 20]. Visszaemlékezése alapján német Fokkert használt [27]. Június 27-én Berényi Sándor egy felvidéki légitámadásból visszatérve, a szétlőtt motor miatt Váccal szemben a Pokol-szigetre zuhant, és kisebb sérüléseket szenvedett [5]. Fényképek

11. ábra. A csehszlovák tulajdonba került 3867-es számú MÁG-motoros schwerini D.VII-es. Jól látható a kései gyártású Fokker tereptarka mintázata, a motorburkoló lemezek és a Schwarzlose géppuska (vinar.cz)

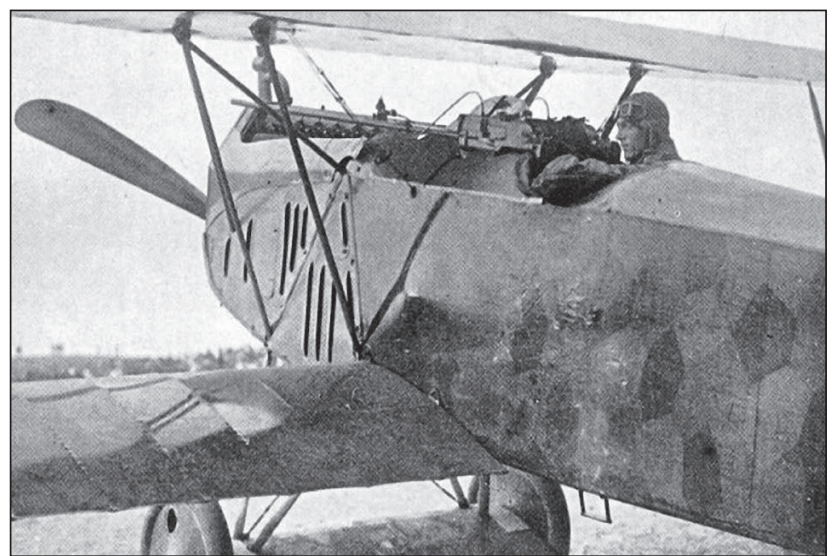




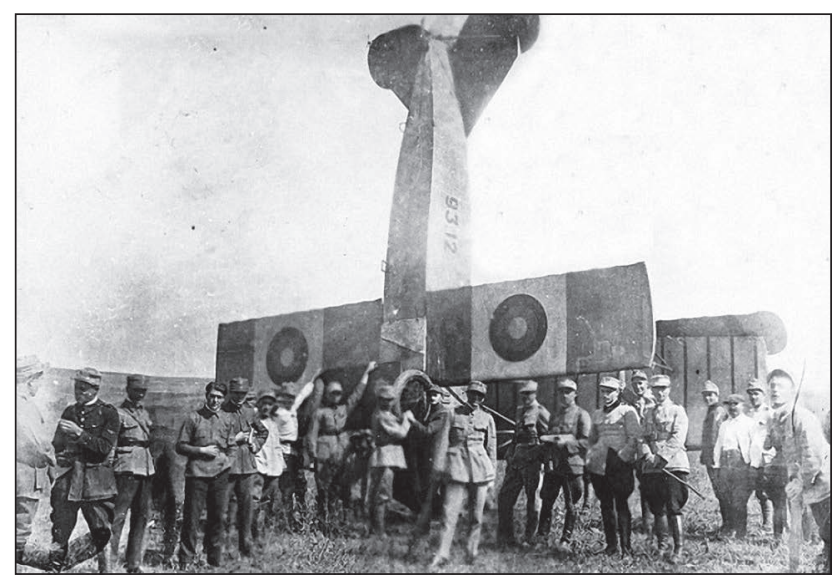

12. ábra. A románoknál orra állt 93.12-es. A MÁG-gyártású Fokkerek színe a valóságban a lakozott vászon miatt világossárga (homokszínú), a motorlemezek festetlen fémszínűek voltak (www.cartula.ro)

alapján tudjuk, hogy a MÁG-gyártású 93.07-es és 93.09-es átvágódott és összetört. Továbbá $3 \mathrm{db}$ javítás alatt lévő D.VII-est a románok foglaltak le az albertfalvai MARE repülőgyárban augusztus elején [24]. A román megszálló csapatok gyakorlatilag lerabolták a teljes repülőgépipart, minden mozdítható értéket, gépeket, repülőket, használható géproncsokat is kiszálították az országból. A román forrásokban ${ }^{3}$ nagyrészt csak a Cinkotai Anyagszertárban zsákmányolt Fokkerek szerepelnek az alábbi lajstromszámokkal:

- együléses gépek: 93.10-93.12, 93.13 sérült, 93.14, 93.15 sérült, 93.16-93.26;

- kétüléses gépek: H.1-196.30, H.4-197.42, H.5-197.44, H.6-197.45, H.7-197.46, H.8-197.47, H.9 kétkormányos, H.10 kétüléses [24, 25].

A többségük Aradra került, egyes források szerint 6 db-ot (HD.09, 93.12, 93.16, a 93.18-ról fotó is készült) használtak kiképzésre - ezt a mennyiséget több kutató is túl kevésnek tartja. Próbáltak alkatrészeket vásárolni hozzájuk Bécsben, de állítólag 1920 után a hadsereg már nem tartott rájuk igényt [24, 25]. A fényképeken szereplő repülőkről hiányzott a géppuska, ez lehetett a selejtezésük valós indoka. A Cinkotáról elvitt repülők fegyvertelenek voltak, hiszen még a HM kárjelentésében sincs külön feltüntetve, hogy onnan géppuskákat raboltak volna el. (A magyarok szinkronizált repülőgéppuska-hiánnyal küzdöttek, lásd a fegyvertelen, vagy az egy géppuskás Berg D.Iesek és Fokker D.VI-osok az alakulatoknál [5, 12, 24].)

Külön fejezetet jelent a HD.09-es sorsa. Mátyásföld megszállása után rögtön az első hullámban vitték el a gyártelepről és repülték át a románok Rákosra, majd Aradra, az erről tudósító MÁG-jelentésben említik a kompletten felszerelt és üzemképes állapotú „H.D.9 sz. Fokker repülőgépet" [8]. A 13. ábra tanúsága szerint a HD.09-es 1920. február 20-án Aradon balesetet szenvedett. A képen jól látszik, hogy a gép kétüléses, tehát a „H” jelzés valós, de honnan a jelzésben a „D” betű? A választ egyrészt a román zsákmánylista adja meg, amiben a $\mathrm{H} .9$ mellett a kétkormányos megjegyzés szerepel, egyedül a felsorolásban. Másrészt a HM kárjelentésben ${ }^{4}$ is szerepel a MÁG alatt „1 db - D (kísérleti) repülőgép - 200 000" tétel a problémás darabszámú D.VI-osok (?) között. A HD.09-es az egyetlen magyar kétkormányos - elsősorban kiképző - Fokkert jelezte $[8,24]$.

Ezenkívül meg kell említeni Fejes István 3867-es számú gépét is, amivel kényszerleszállást hajtott végre. A Fokkert a csehszlovákok üzemképes állapotba hozták. A német

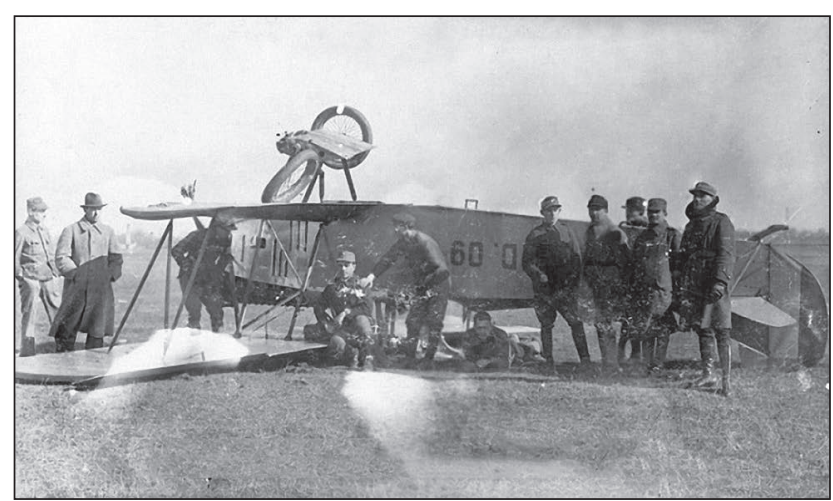

13. ábra. Az Aradon összetört kétkormányos Fokker, a kiképző feladatú HD.09-es (www.cartula.ro)

gyártású, de MÁG-motoros Fokkert 38.67-es lajstromszámmal 1922-ig műrepülőgépként használták, és 1925ben selejtezték le $[5,6]$.

A Dunántúlra benyomuló Nemzeti Hadsereg szétverte a még ellenálló vörös alakulatokat, de a katonák többsége köztük a megmaradt repülőalegységek - átállt hozzájuk. Szombathelyen a repülőgépek csillagait fehérre mázolták, rájuk pedig fekete $\mathrm{H}$ betűt festettek. $\mathrm{A}$ vegyes összetételü század a visszavonuló felderítőszázadok megmaradt repülőivel is megerősödött. A parancsnok Háry László százados lett. A század néhány röpcédulaszóráson kívül föleg futárszolgálatot végzett a különböző repülőterek között [9, 12, 19].

November 14-16. között a Nemzeti Hadsereg bevonult Budapestre. Siófokról és Szombathelyről nyolc repülőgépet Bicskére telepítettek át, ebből három D.VII-est. Feladatuk az volt, hogy felderítsék a gyülekező csoportokat, a karhatalmat a levegőből (üzenetledobással) támogassák, és a kapcsolatot fenntartsák Bicske, Albertfalva, Vár parancsnokságok között. Mivel nem volt rendbontás az ünnepélyes bevonuláson, így a repülők a díszmenetet egészen a Parlamentig kísérték, miközben röpcédulákat szórtak. Ezekkel a gépekkel töltötték fel a korábban megalakított budapesti repülőszázadot. A Szombathelyen maradt század további két működőképes Fokkert jelentett decemberben. A siófoki különítmény és a szegedi két század (egyik kiképző) csak kétülésesekkel rendelkezett [9, 12, 19].

1920 januárjában - a trianoni békediktátumot előkészítő rendelkezések nyomán - a repüléssel kapcsolatos ügyeket sürgősen a Kereskedelmi Minisztérium hatáskörébe utalták. Létrehozták fedőszervként a civil Magyar Aeroforgalmi Rt.-t (Maefort). Légipostát, hírlapokat, ritkán utasokat is szállítottak a vidéki repterekre, közbenső városokra pedig ejtőernyővel dobták le a csomagokat. A Maefort keretében egy vadászszázadot (6+4 együléses), egy kétüléses $(9+6)$ századot, egy kiképzőszázadot (Szeged, Szombathely) állítottak fel javítóműhellyel és anyagszertárral. Ahol a postaforgalmon kívül a repülőgépvezetők gyakorlatait, a veterán megfigyelő tisztek pilótává való átképzését, valamint az ejtőernyős ugratásokat végezték [3, 9, 12, 19]. A katonai repülőgépeket polgárivá alakították, fegyvereiket leszerelték, néhányba például sportülést is szereltek, a repülőkre pedig betűkből és számokból álló polgári lajstromjeleket festettek (fehér sávra feltűnően nagy betűket).

Az Ausztriától vásárolt Phönixeken kívül a megmaradt nyersanyagokból a magyar repülőgyárak hozzávetőleg 40 db repülőt készítettek és adtak át a repülőcsapatoknak, köztük néhány új $D$.VII-est ${ }^{5}$. A szegedi javítóműhelyben pedig számos használt repülőt állítottak ismét üzembe, köztük az alábbi (J, azaz „Javított”) lajtromszámú D.VII-eseket: H-J.82, 


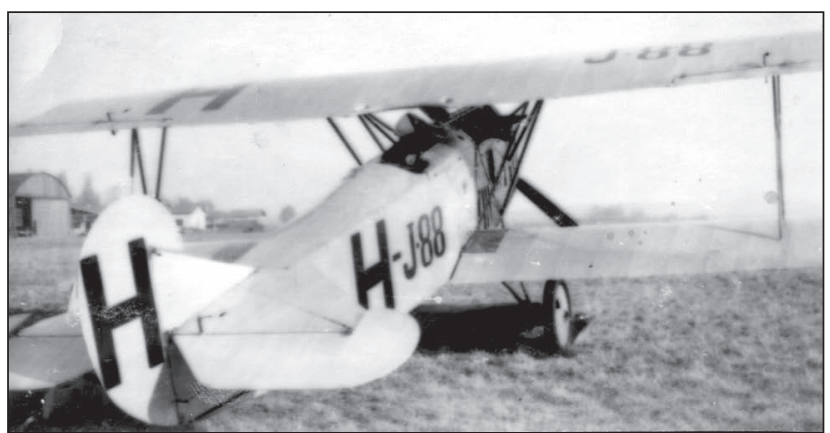

14. ábra. A H-J.88-as jelzésű D.VII-es a Nemzeti Hadsereg állományában. A szegedi javítómühely számos használt repülőgépet helyezett ismét üzembe (Fotó: Zainkó Géza gyűjteményéből)

H-J.84, H-J.87, H-J.88. A MÁG további megrendelést kapott $36 \mathrm{db}$ kétüléses Fokker C.I-es megépítésére, de ezeknek a gépeknek az elkészítéséről nincs adat [9]. 1921 elején napvilágot láttak a trianoni békeszerződés repüléssel kapcsolatos pontjai, ezért az E-akció ${ }^{6}$ részeként a jó állapotú D.VII-eket Szegedre szállították. Április 21-én 5 példányt a szeged környéki Szűcs-féle pincékbe fuvaroztak, majd az elrejtés után a pincéket visszafalazták. (Március 1-én a H-J.84-et a Gárgyán majorban már korábban eltárolták.)

Csak 1922 végén oldották fel a repülési és repülőgépgyártási tilalmat, de Magyarországon továbbra sem engedélyezték a katonai repülést. A korábban elrejtett D.VIIesekből 1924-ben 4 példány egy titkos modernizáláson esett át a légierő Székesfehérvár-sóstói javítóüzemében. Lóczy Sándor mérnök (aki korábban a Fokker Műveknél dolgozott) és Fabinyi Elek mérnök százados vezetésével először a törzshöz új szárnyakat építettek és a törzsszerkezetet is részben átalakították $[12,23,156$. o.]. Majd a fafelületeket és a vászon burkolatokat újították fel. Erősebb, 240 LE-s Hiero motorokat építettek be, amelyeket hivatalosan 1923 decemberében a Fokker utasszállító repülőgépek számára hozattak be az országba, de csak két F.III-as kapott ilyet. A D.VII-eket H-MFOA-tól H-MFOD-ig vették nyilvántartásba, áttérve a nemzetközi standard 5 betűs jelzésrendszerre $[3,12]$. A betűlajstromozás mellett titkos katonai azonosítószámot is kaptak 03.01-től, ahol a „0" külföldi származást, a „," Sóstót jelölte. A Fokkerek álcázásként mürepülőgépekként kerültek nyilvántartásba, és a pilóták civil ruhában repültek rajtuk.

Először a korszerüsített D.VII-eseket szerelték fel a magyar légierő ultramodern fegyverével, a Gebauer Ferenc által titokban kifejlesztett GMP-vel (Gebauer Motorhajtású Puskával). Ezzel a 7,92 mm-es ikergéppuskával - a motor tengelyforgásától függően - már 1600 lövést lehetett leadni percenként. Szombathelyen 1924. december 18-án a tüzérosztálynál a földön bakról, majd 30-án Székesfehérváron az egyik Fokkerbe szerelt 22M GMP-vel a földön, majd a levegőben - különböző magasságokban - végeztek sikeres lőteszteket. Az eredmények alapján döntött a HM arról, hogy GMP-vel szereli fel a titkos légierő repülőgépeit [13]. A vadászgépekbe már a továbbfejlesztett $26 \mathrm{M}$ GMP-ket építették be. 1928. november 17-én Székesfehérváron a megfelelően beszerelt $26 \mathrm{M}$ átlőtte a D.VII-es légcsavarját, ezért Gebauer javított, sorozatgyártásra alkalmas változatot tervezett 26/31M ${ }^{7}$ GKM (Gebauer Kényszermeghajtású Motorgéppuska) jelöléssel, amely egyik alapfegyvere lett a második világháborús magyar harci repülőknek [12, 13, 26, 17-18. o.]. Ehhez kapcsolódik, hogy a HM ragaszkodott az itthon készített lőszerekkel való próbákhoz, emiatt csúsztak a tesztek, mivel csak 1929

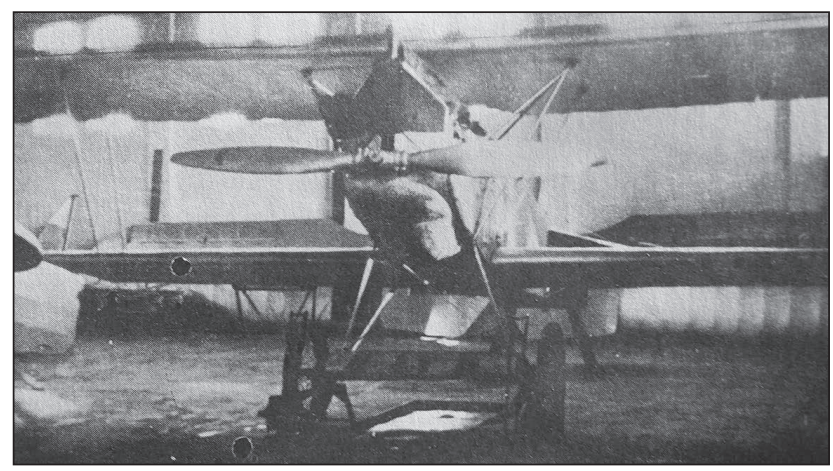

15. ábra. A sóstói Fokker D.VII-es. Egyik ismérve, hogy a Hiero motor miatt az alsó motorlemez „hasas” formájú a korábbi Daimler motoros, laposabb verzióhoz képest [3]

decemberében érkezett meg a 200000 db magyar gyártású Mauser töltény a kísérleti csoportnak [13].

Az 1924-ben újraindult titkos katonai pilótaképzésben való részvételben meghatározó volt a „sóstói” Fokkerek szerepe. Már 1926-ban a Ludovikán 20 tiszt letette az esküt, majd rangjukról „lemondva” átkerültek a Légügyi Hivatal állományába. Belőlük faragták a már ismert repülőászok a következő harcipilóta-gárdát. A katonai repülési tilalom enyhüléséig óriási szolgálatot tettek a vadászgéphiánnyal küszködő rejtett légierőnek [12, 20].

A repülők rejtés céljából Szegeden és Szombathelyen is állomásoztak időjelző csoport fedőnév alatt, ami először a Háry László főfelügyelő vezette repülő kísérleti csoportot, később a kísérleti vadász századot fedte. 1930-34 között pedig már a Turul 1. vadászcsoportban szolgáltak Székesfehérváron, egyre fogyatkozó példányszámban. Akkoriban a csak harci kiképzésre használt D.VII-esek festése továbbra is polgári volt: a függőleges vezérsíkra „H” betű került, de a fehér hátteret a betűlajstromnál már nem használták. Új civil betűjelzést (HA-FOA-tól) és új titkos azonosítási számot (30.01-től) kaptak, ahol a 3-as szám a vadászgép kategóriát jelölte. Felségjeleket azonban csak az 1930-as évek elején tartott nagy hadgyakorlatokon festettek rájuk, pl. az 1931 nyarán megtartott Csaba hadgyakorlaton a piros-fehér-zöld sávokba berajzolt kettőskeresztet. Ezen a gyakorlaton 2-2 „Fokker khaki” színű [26] D.VII-es és D.XVI-os vadász kísért 17 db C.VD közelfelderítőt. A következő évtől azonban a katonai repülőgépek farokfelületeit piros-fehér-zöld sávokra osztották, így különböztetve meg a polgári gépektől [3, 12, 20, 21].

16. ábra. A HA-FOD polgári lajstromjelü repülögép roncsa a Közlekedési Múzeum Hermina úti épületét ért 1944-es bombázás után (Forrás: Közlekedési Múzeum Évkönyve 10.)

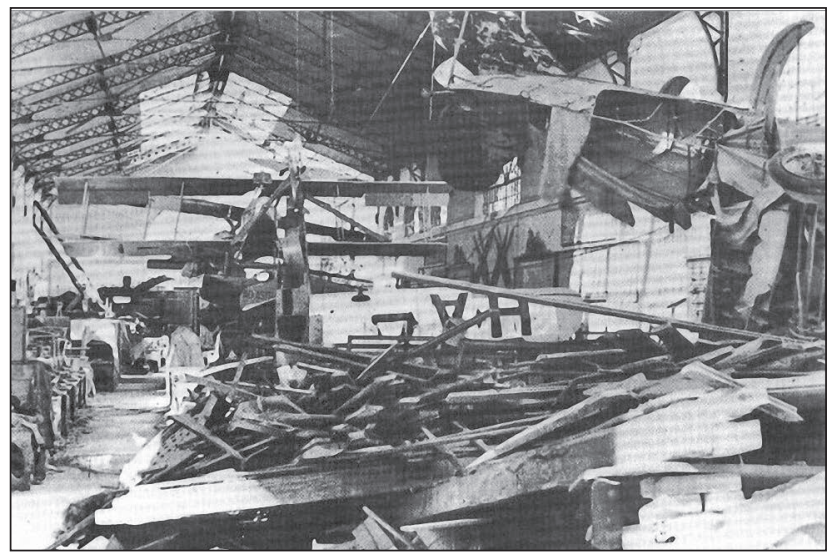


1935-ben a magyar D.VII-eseket leselejtezték, a HA-FOD - igazi nevén 30.04-es - jelzésű példányt a Magyar Királyi Közlekedési Múzeumnak adományozták. A múzeum 1935-ös tárgymutatója ${ }^{8}$ szerint a 2327. számú kiállítási tárgy Fokker üzemében készült 1918-ban, felújították Székesfehérváron, és a motorja 1918-as építésű 200 LE-s Daimler volt.

A repülőgép 1944. szeptember 17-én egy bombázás során megsérült. Később az ostrom és az azt követő fosztogatások tovább rontottak a helyzeten. Az 1946-os állományjelentésben még szerepeltették, de az 1950-es években ismeretlen okokból megsemmisítették [3, 12].

A cikk elkészítéséhez a szerző saját, valamint részben Czirók Zoltán friss kutatásaira támaszkodott.

\section{ForRÁsOK}

[1] Batchelor, John; Lowe, Malcolm V. A repülés enciklopédiája 1848-1939, Budapest: Gabo. 2005;

[2] Boksay Antal. A felhők katonái. Budapest: Aquila, 2001;

[3] Bonhardt Attila, Sárhidai Gyula, Winkler László: A Magyar Királyi Honvédség fegyverzete. Budapest: Zrínyi, 1992;

[4] Brannon, Edgar. Fokker D.VII in action. Squadron/ SignalCarollton, 1997;

[5] Czirók Zoltán. „Az első légi háború Magyarország felett - 1919." Hadtörténeti Közlemények 124. évf. 2. sz. (2011). 335-364 p. http://epa.oszk. hu/00000/00018/00053/pdf/EPA00018_ hadtortenelmi_2011_2_335-364.pdf;

[6] Czirók Zoltán. „A magyar repülőcsapatok 19181919. évi történetéhez" Hadtörténelmi Közlemények, 122. évf. 3. sz (2009): 603-634. p. http://epa.oszk. hu/00000/00018/00060/pdf/EPA00018_ hadtortenelmi_2009_03.pdf;

[7] Czirók Zoltán. „Repülőszázadok Ongán - 1919.” 1. rész Ongai Kékdaru. 2009. november 10-11. o. 2. rész Ongai Kékdaru. 2009. december 11. o. 3. rész Ongai Kékdaru. 2010. január 10-11. o. 4. rész Ongai Kékdaru. 2010. február 10-11. o. http://www.okeonga.hu/documents/om/repsz.pdf;

[8] Czirók Zoltán. „Hadirepülők Rákoson (1918-1919).” Magyar Repüléstörténeti Társaság évkönyve, 2011. 33-48. o. http://iwk.hu/_userfiles_/aviatika/033_048\%20CzirokZoltan\%20-\%20 Hadirepulok\%20Rakoson.pdf;

[9] Czirók Zoltán. „Az „E-akció”, avagy kísérlet a magyar katonai aviatika megmentésére - 1920-1921.” Hadtörténelmi Közlemények 126. évf. 3. sz. (2013): 791-801. p. http://epa.oszk.hu/00000/00018/00028/ pdf/EPA00018_hadtortenelmi_2013_3_791-804.pdf;

[10] Czirók Zoltán. Katonai repülők Mátyásföldön (1918-1919). Magyar Repüléstörténeti Társaság évkönyve, 2014. 54-70. p.;

[11] Czirók Zoltán. „Német repülőgépek a Balkánról.” A Repüléstörténeti Konferencia Közleményei, 2009. 168-172. o. http://iwk.hu/ userfiles /aviatika/168\%20CzirokZoltan\%20NemetRepulogepek.pdf;

[12] Csanádi Norbert, Nagyváradi Sándor, Winkler László. A magyar repülés története. Budapest: Műszaki, 1977;

[13] Gáspár Ferenc, Mann Miklós. Danuvia 50 éve. Budapest: Danuvia, 1971;

[14] Gerencsér Miklós. Az északi arcvonal. Budapest: Szépirodalmi, 1989;

[15] Gunston, Bill. Korszerü harci repülögépek fegyverzete. Budapest: Zrínyi, 1995;
[16] Horváth Lajos. Katonák a Rákos és a Galga mentén. Gödöllő: Műv. Kp., 1989;

[17] Knight, Brian. Fokker D.VII Anthology I., II., III. Albatros Publishing, 2002;

[18] Liptai Ervin. Vöröskatonák, elöre! Budapest: Zrínyi, 1979;

[19] Magyarország az Első Világháborúban. Lexikon. Budapest: Petit Real,1999;

[20] Nagyváradi Sándor, M. Szabó Miklós, Winkler László. Fejezetek a magyar katonai repülés történetéből, Budapest: Műszaki, 1986;

[21] Pataky Iván, Rozsos László, Sárhidai Gyula. Légi háború Magyarország felett I-II. Budapest: Zrínyi, 1992;

[22] Jackson, Robert. Air War Flanders-1918. Airlife Publising, 1998;

[23] Winkler László. „A magyar repülőtechnika 50 éve (1916-1966)" Technikatörténeti szemle 4. Bp.: 1967;

[24] Aero História, Közlekedési Múz. 1989/jún., 1989/dec., 1990/dec., 1992/okt.;

[25] Air Enthusiast, No. 60, 61, 62;

[26] Haditechnika 27/2. sz. (1993), 30/2. sz. 10-15. o., 30/4. sz. 77-79. o. (1996), 43/4-5. sz. 15-19. o, 14-18. o. (2009);

[27] Magyar Szárnyak 1939/05.

[28] Peter Grosz. Austro-Hungarian Army Aircraft Of World War I. Paladin Press, 2002

[29] „Fokker D.VII - Drawings”. Elérés 2020. március 24. https://www.fokkerdvii.nl/;

[30] Dokumentumgyüjtemény: A magyar Vörös Hadsereg 1919-ben. Bp.: Kossuth, 1959;

[31] „Welcome to The Aerodrome - Aces and Aircraft of World War I". Elérés 2020. március 24. http://www.theaerodrome.com/index.php;

[32] „WWI Aces and Airplanes - New Weapons of the Great War". Elérés 2020. március 24. http://acepilots.com/wwi/.

\section{JEGYZETEK}

1 Az 1919. május 28-i végleges átszervezésnél minden századot a "vörös" jelzővel is elláttak.

HL, MTK iratai. 737/bk. 27. d. A „vörös” jelzőhöz a rendelet megjelenését követően maga a Repülőcsapat parancsnokság sem ragaszkodott, a kiadott parancsnokban ugyanis következetesen elhagyták ugyanúgy, ahogy az egyes századok is mellőzték jelentéseikben szinte kivétel nélkül [8]

2 Zárójelben a pilóták igazolt és a nem igazolt világháborús légi győzelmei.

3 Valerin Avram: „A román V. repülőosztály tevékenysége Magyarország felett” (ford. Bemád Dénes) Aero História 6 (1992. október): 32-41. o.

4 Bernád Dénes: „A Román Királyi Légierő első magyarországi hadjárata 3. rész" Aero História 5 (1991 aug.): 39-46. o.

$5 \mathrm{Az}$ 1920-ban épült D.VII-esek lajstromszámát (de egyáltalán a jelzések rendszerét) több kutató is próbálta kideríteni, de a hiányos források miatt eddig nem sikerült. Az eddig beazonított új vadászrepülők és oldalszámaik: MÁG Berg D.I., H-AA.1-4. (4 db); Lloyd Berg D.I., H-OA.1 (1 db); osztrák Phönix D.III., H-PD.1-2. (2 db); MÁG Fokker D.VI., H-AF.1-2. (2 db) [3, 9].

6 Az 1920-as évek katonai irataiban „E”-vel jelölték a „kényes” ügyeket, amely az „Entent”-re vagy az „Ellenőrzés”-re való utalást jelentette [9].

7 A GKM-be beépített új rendszer megakadályozta a légcsavar átlövését. Gebauer Ferenc mérnök az I. világháború végén, Aspernben már sikeresen tesztelte az 1918M jelzésű modelljét.

8 Forrás: Magyar Királyi Közlekedési Múzeum. Tárgymutató (Budapest, MKKM, 1935) 